\section{Equal Justice}

Eric Rakowski, 385 + xii pages, Oxford, 1991, Clarendon Press, $£ 40.00$.

Professor Rakowski begins his book with a quote from Aristotle's Politics: 'All hold that justice is some kind of equality'. His own account of an egalitarian conception of distributive justice in this outstanding book ranks alongside the pioneering work recently done in this area by writers such as John Rawls and Ronald Dworkin.

Rakowski's answer to the question of how scarce resources are to be shared around he calls 'equality of fortune', and his defence of this notion takes up the first half of the book. Like G A Cohen, Rakowski believes that the essence of egalitarianism lies in evening out the effects of 'brute' bad luck, that is, ill fortune which is not the result of risk incurred by the agent. Inequalities arising from chance require a redistribution of resources, and 'resources' here include physical and mental capacities. Ideally, each should start life with equally valuable resources, subject to two caveats: there is some presumption in favour of allowing gifts and bequests to children; and great sacrifices cannot be called for from the more fortunate. Rakowski's is not merely a 'starting-gate' theory. Equality of fortune as a general ideal along with a stress on the importance of personal autonomy - requires the establishment of various insurance schemes, and the details of these are developed carefully in the book.

Theories of justice are often set in opposition to utilitarianism, and here Rakowski's thesis looks particularly strong: why should someone who has already been dealt a bad hand by fate suffer yet more at the hands of morality on the ground that he or she will be an inefficient consumer of resources? Like Rawls, Rakowski offers us a view of 'justice as fairness'.

Rakowski closes Part I of the book with a chapter on whether transferable organs or blood should be seen as resources subject to redistribution. $\mathrm{He}$ argues that they should be, and that in certain circumstances compulsory extraction of, for example, blood might be justified. This would be unusual, however, if his recommendation that post mortem extractions be the norm were adopted.

Part II of the book defends an account of strict liability which may be useful to those interested in medical negligence. In particular, Rakowski's attack on the idea that tort law is to be understood in wealth maximising terms is such that this view must henceforth be consigned to the dustbin of philosophical history.

In Part III, Rakowski returns to the more straightforwardly medical ethical issue of the allocation of life-saving resources. He argues that numbers are relevant in life-saving decisions, but not because it is objectively better if, other things being equal, a larger group survives. Rather, we are each required now to form an intention to save the larger group in any such case, since this is in the interest of all.

Rakowski dedicates a chapter to considering whether particular characteristics of persons, such as age or moral character, should influence choices between lives. His subtle discussion concludes that only (i) large differences in age and (ii) the individual's responsibility for his or her plight are relevant. He ends the book by defending a rights-based view against, in most circumstances, killing one being to benefit others.

I disagree with some of Rakowski's negative arguments, acute as they are; but his sophisticated and humane account of justice is among the most powerful and persuasive I have read. His discussions of medical ethical questions will be the starting point for those who address these questions in future. This is a book that deserves to be - and no doubt will be - taken very seriously indeed.

ROGER CRISP, Fellow in Philosophy, St Anne's College, Oxford.

\section{AIDS: an Epidemic of Ethical Puzzles}

Edited by the Hastings Center, USA, 187 pages, Dartmouth, 1991,

Gower Academic Publishing Group, $£ 32.50$ hc.

The acquired immune deficiency syndrome, with its undertones of sexuality and a pervasive fear of contagion, has been the catalyst for a revolution in professional ethics. The issues of patient autonomy, the conduct of placebo control trials, the rights of confidentiality, informed consent, death with dignity, and the obligations to provide care for individual health care workers are all explored in this recent collection of papers from the
Hastings Center.

What struck me most forcibly, on reading this book, was the major shift in ethical perceptions during the AIDS epidemic. The early paternalistic pronouncements from professional bodies have been modified in the light of experience and have lost some of their lofty tone. It is helpful in the present difficulties of the National Health Service to recognise that in Britain there has long been a consensus of an entitlement to health care by all and a less well expressed view of the obligation of individual health-care workers to provide such treatment. Such a consensus does not exist in the United States where health care is not freely available to all and professional bodies jealously cherish the right of doctors to act as independent contractors and to refuse to provide health care. Human immunodeficiency virus infection is slowly altering this perception with many States enacting anti-discriminatory legislation.

The other fascinating aspect of this collection of papers is a thoughtprovoking review of the obligations and opportunities of researchers in the Third World. The changes in ethics occurring in different social and cultural situations are clearly? expounded.

As a lay reader I am always left vaguely disappointed that this sort of book does not provide a few simple rules which would guide me in day-today ethical decisions. I am, however, reassured when I discover that people who have made the study of ethics their lifetime's work face the same difficulties. This book is a fascinating historical account of the ethical dilemmas produced by the AIDS epidemic and makes a thoughtprovoking change from the average textbook, although it is rather expensive at $£ 32$.

BRIAN GAZZARD Consultant Physician and AIDS Co-ordinator, Westminster Hospital, Dean Ryle Street, Horseferry Road, London SWIP 2AP.

\section{Family Rights: Family Law and Medical Advance}

Edited by Elaine Sutherland and

Alexander McCall Smith, 135 pages, Edinburgh, 1991, Edinburgh Press, $£ 25.00$. 